\title{
Local Democratic Governance and Transnational Migrant Participation
}

While mobilized from abroad, migrant partnerships with the sending state are coordinated in preexisting social and political conditions in places of origin. Local social relations and political factors shape who becomes involved in partnerships, whose interests are represented, and the quality of the deliberations during project negotiations. How involved local citizens and government authorities are in the transnational process with migrant partners organizes partnerships differently. In this chapter, I argue that the combination of community inclusion and government engagement shapes transnational arrangements, creating four main types of partnership: synergetic, corporatist, substitutive, and fragmented.

The central argument is that transnational partnerships that are broadly inclusive of residents' input and reflect the full engagement of local political officials facilitate new modes of interaction between local citizens and elected representatives. This interactive process entwines state and society in local governance. Migrants' horizontal ties in the community and vertical ties to local government create conditions ripe for a more politically engaged local citizenry and more responsive governance. Other factors such as the length of time migrants have been abroad, the intensity of emigration in the hometown, and the size of the origin community are important, but these factors neither straightforwardly determine successful coproduction of public works nor determine changes in local political and civic engagement. Rather, the ability of migrant leaders to overcome the array of challenges inherent to collective action from abroad hinges on social and political institutions and resources in the hometown and are captured through the concepts of community inclusion and government engagement. 


\section{COORDINATION OF TRANSNATIONAL PARTNERSHIPS \\ IN THE SOCIAL BASE OF THE HOMETOWN}

The coordination of public goods provision between migrant actors (and their groups) and political officials is a fluid process that occurs in the social base of the hometown. ${ }^{1}$ By "social base" I am referring to the structure of the relational setting composed of a set of social ties and interactions among a set of actors that enables them to act collectively. ${ }^{2}$ Migrants' collective remittance resources create vertical ties to government actors that contribute complementary resources for local public goods provision, which forms the organizational basis for transnational coproduction to occur. But migrants are also socially embedded in their places of origin to varying degrees. I argue the extents to which migrants maintain and construct horizontal ties and practice cultural repertoires that confer community membership are the most important determinants of the breadth and depth of community inclusion in the coproduction process. When migrants participate in public goods provision, how well they remain integrated into the social base of the hometown and their ability to overcome perceived differences in status brought about by migrating abroad play significant roles in how effective their partnerships with sending state actors will be and the political outcomes that result.

\section{EFFECTS OF INTERNATIONAL MIGRATION ON SOCIAL TIES AND COMMUNITY MEMBERSHIP}

Distance from the place of origin and exposure to new influences, attitudes, behaviors, and customs create separation from people remaining behind. Some migrants are fundamentally changed by the migratory experience, which introduces modes of disconnection between sojourners and stay-at-homes. The length of time abroad attenuates migrants' web of contacts in the home place, constricting individual ties to more narrow circles of familiars. Demands on time, cost of travel, and legal status barriers to regular home-country visits reduce HTA members' exposure to and knowledge of conditions in the home place. Migrants' social and physical distance from the hometown leads to ideational gaps between "here" and "there" that likely constricts migrants' social ties to a diverse set of social actors and stakeholders in the hometown community.

The social distance created by emigration is not so different from other kinds of departure. Take, for example, changes in social status that occur when people go away for college. While going to college is a privilege in its own right, some high school graduates have the additional luxury of being able to go to a school in a different part of the home state or in a different state altogether. Time away in some different place exposes sojourners to new experiences, ideas, and behaviors. College-goers meet new friends across campus from different parts of the country, they become more mature, and they learn new things about themselves and about 
the world they live in. As people get older, work, and play together, they develop meaningful relationships that continue to inform who they are and where they want to go. Like college-goers, migrants often see their hometowns and the people remaining behind through a new lens after experiencing life in a new place.

Sometimes the distance produces nostalgia and a strong desire to return to familiar ways of life. But for others the psychological and emotional journey to somewhere else and the experiences afforded to them in new places create social divisions and noticeable differences between those who go and those who stay. When migrants, like college grads, have achieved some upward mobility because of their emigration, their material resources and ideas about the world that result from living abroad may affect social status at home. Migrants' experiences living abroad and acquisition of income lead some to adopt new attitudes and enables them access to land, new language, manners, customs, and dress. ${ }^{3}$ These differences between here and there arising from migration may exacerbate social divisions already present and generate new cleavages between those who stay and those who go, which complicates migrants' claims to continued membership in the hometown community after they go abroad.

Places of origin are not frozen in time during migrants' absence either. While migrants work and live in the destination, people go on living, working, and engaging in the social, economic, cultural, and political life of the sending community. Children go to school. Political incumbents win and lose. Families invest in housing improvements, start businesses, and care for the sick and elderly. Couples marry and break up. Scandals, gossip, festivals, celebrations, traditions, and all manner of social and cultural life continue even as migrants come and go, video chat with family and friends, and build more permanent lives in the destination.

In some places, as emigration increases, communities become more transnationally oriented. ${ }^{4}$ Residents with migrant ties or in places with high rates of emigration become more aware of and interested in the culture and society of the destination country. Substantial emigration changes many immigrants and it changes people remaining behind as well. These changes that accompany substantial emigration mean that some migrants are more likely to be embedded in the social base of the hometown after exit while others are less so.

Moreover, it is not enough to have social connections. Migrants must also be able to overcome perceived status differences between them and the stay-athomes. When migrants continue to partake in cultural norms and values that are meaningful for group solidarity in the homeland, they signal to those at home that even though they have left and have become more prosperous they still belong. Migrants who are more socially embedded have both breadth and depth of social network ties in the hometown community and they are more likely to include local residents as active partners in the transnational process of coproducing public goods. Community inclusion has important consequences for civic and political engagement in local governance. 
MIGRANT SOCIAL EMBEDDEDNESS AND

MEMBERSHIP IN THE HOMETOWN COMMUNITY

Migrant embeddedness depends on the maintenance and construction of social ties and continued engagement with cultural repertoires that signal community membership. In this context, the relevant migrant actors are those individuals who are the active leaders or ambassadors of the migrant club in the hometown. Migrants' social embeddedness is key to understanding which residents are active participants in the coproduction process because it informs whose interests are being represented in negotiations with local government actors. This inclusiveness has important implications for the scaling up of local civic and political engagement in project governance and the likelihood that local participation spills over into other forms of democratic engagement.

Embeddedness is also crucial because it mitigates legitimacy issues that arise when migrants make decisions in town affairs from abroad. I expect that migrants who are more socially embedded will be able to substantively participate in the public affairs of the hometown as if they were territorial citizens because residents and community leaders still perceive them as members of the social and political community. In other words, making legitimate political decisions in public affairs from beyond borders is predicated on the belief of those remaining behind that migrants still belong to the community in a meaningful way. Migrants who maintain or construct more extensive social ties in the hometown, fulfill social, religious, and ethnic obligations, and practice quotidian cultural repertoires of social solidarity are more likely to be perceived as group members regardless of their territoriality and to include residents in the coproduction process. And while migrant individual characteristics and cultural practices matter for their belongingness so too does the structure of social ties in the hometown community.

By "community," I am referring to territorial (local resident) and extraterritorial (migrants who live abroad) citizens who share common attachment to the territory of the municipality or locality where public goods projects are provided in the coproduction process. ${ }^{5}$ In this context, the concept of community extends beyond the confines of the political territory of the nation-state to those who are citizens abroad and who have a juridical claim to citizenship based on jus solis (birthright citizenship, or "right of the soil") and jus sanguinis (one or both parents being citizens, or "right of blood") laws. The important distinction here is that while migrants may retain juridical citizenship claims to participate in their places of origin, their absence calls into question whether or not they still belong.

Since public goods decisions are not binding on migrants because they live abroad, when migrants take an active, collective role in making decisions regarding public projects by mobilizing their remittance resources, residents may not perceive those decisions as legitimate if they have not had a meaningful part in their formation. ${ }^{6}$ To increase the likelihood that public goods project decisions 
have legitimacy when they are transnationally coordinated, either local citizens are included in the decision-making process, or migrants who represent community interests are perceived as social and political members of the hometown such that when they make decisions about public goods projects, their decisions are articulations of local residents' interests. ${ }^{7}$ There is an inherent tension in extraterritorial migrant citizens acting on their juridical citizenship claims to substantively participate in local political decisions in places where they no longer physically reside. As such, the recruitment of local citizens into the coproduction process is an important factor in determining the successes and failures of projects and possibilities for more democratic participation in local governance. We need to know who is involved in helping migrants and political officials make public goods decisions to know how egalitarian the process is. Understanding the structure of migrant social ties in the hometown shows us the way.

\section{MIGRANT BONDING AND BRIDGING SOCIAL TIES IN}

\section{THE HOMETOWN}

The structure of migrant social ties in the hometown determines the degree of community inclusion. Migrant ties are best characterized by a combination of two types of social ties: bonding and bridging ties. The migrant bonding network includes people who are similar in terms of their demographic characteristics such as kin (consanguine and affinal) and fictive kin relationships. ${ }^{8}$ Most often, migrants are bonded to family and close friends remaining behind as well as other migrant households in the origin community as these relationships entail trust and reciprocity. Bonding social ties are also the most likely to endure after emigration. When migrants needed help with transnational public projects, they most often initially recruited from this network.

By contrast, bridging ties are social ties to people who do not share many characteristics and tend to be beyond migrants' immediate social circles. ${ }^{9}$ Bridging ties are more outward looking and encompass people with diverse socioeconomic characteristics, whereas bonding ties are more inward looking and reinforce exclusive identities and more homogenous, similar characteristics. Bonding ties undergird reciprocity and mobilize solidarity, but bridging ties serve as links to external assets and improve information diffusion by generating broader identities and nurturing relationships of reciprocity. ${ }^{10}$

The bonding and bridging ties ${ }^{11}$ that make up migrants' social base are not either-or categories that neatly divide social networks. Rather, the membership of migrant HTAs has both bonding and bridging ties; however, bridging ties tend to be in shorter supply. Assessing the inclusiveness of coproduction in terms of the extent of bonding and bridging social ties in the hometown is key to understanding how reflective the coproduction process is of different interests and 
needs in the hometown setting, especially those of more marginalized citizens and citizen groups. ${ }^{12}$

Robert Putnam argues that without bridging ties, such as those that cross various social divides based on religion, class, ethnicity, gender, and socioeconomic status, bonding ties can become the basis for the pursuit of narrow sectarian interests. ${ }^{13}$ Community inclusion that is reflective of both bonding and bridging ties is indicative of greater representation of societal interests. Smaller communities and those with strong ethno-religious institutions like usos y costumbres, a traditional self-governance system based on indigenous customary law, may be more likely to have preexisting bridging ties with migrants abroad. Moreover, destination country place-based characteristics, including the size of the hometown clubs' membership base, may influence the extent of the bonding and bridging ties in the social base that migrants can draw on to coordinate public goods projects.

In sum, the extent to which migrants are socially embedded in the hometown is defined by the social ties they retain after their departure. Those ties are most often bonding social ties to family, close friends, and neighbors. While some migrants maintain social connections to a wider network of people in the hometown, these ties are often in shorter supply and most likely in places with ethno-religious institutions. The combination of bonding and bridging social ties connects migrants to their hometown community and determines the initial recruitment of local citizens in the transnational process of planning and implementing public goods. The overall structure of these ties matter for understanding the effect of transnational partnerships on changes in political and civic participation in the hometown because who is involved in the process determines whose interests are represented and which groups gain access to political officials.

If bridging ties are limited or nonexistent in the migrant social base they can still be created. Some migrant club members may forge new bridging ties through community outreach and recruitment initiatives through existing institutions, elites, and infrastructures. ${ }^{14}$ In other instances, local residents may request access to project planning or insert themselves into the coproduction process if they feel excluded. Locals who are stakeholders or leaders in public affairs in the hometown may challenge the legitimacy of migrant club involvement in public goods provision if club members do not seek their consultation or respect their social status. Recruitment of bridging ties with key stakeholders in the community is critical if migrants want their hometown investment and participation to have broad support and they want to thwart contests for power and authority.

Social interactions with residents outside migrants' bonding network in the hometown may lead to the expansion of bridging ties and the incorporation of a broader swath of societal interests into the coproduction process. Through recruitment initiatives, introductions, and repeated social interactions with local residents beyond migrants' immediate social circle, bridging ties are often constructed. And 
these new social actors representing diverse interests in the community are incorporated into the public goods process.

To summarize, the construction of new bridging ties in the migrant social network that accompanies repeated, cumulative interactions over the course of coproducing public goods projects enables migrants and stay-at-home citizens to learn ways to confront conflict and problem-solve through deliberation and negotiation. Since the construction and maintenance of both bonding and bridging ties that embed migrants in the social fabric of the hometown community can be quite challenging, community inclusion is more likely to reflect migrants' narrower bonding network to the exclusion of others. While I argue that, on average, community inclusion is more likely to be narrower, I also emphasize that social learning through repeated coproduction projects does allow for the expansion of social network ties that leads to increases in community inclusion in the coproduction process. The construction of more heterogeneous social ties in the hometown is possible, even if migrant social embeddedness is rather limited at the outset.

\section{CULTURAL REPERTOIRES, COMMUNITY MEMBERSHIP, AND MUTUAL RECOGNITION}

Social relations between migrants and territorial residents are important, but the basis of social membership is also instantiated, in part, on the practice of cultural repertoires that are meaningful to community members. By "cultural repertoires" I am referring to cultural ideas, rituals, customs, traditions, activities, pastimes, and practices that convey social solidarity and community. Social ties and interactions between migrants and residents in the social base of the hometown are easier to have when migrants continue to practice cultural repertoires that are meaningful to the residential members of the hometown.

In this formulation, cultural repertoires emphasize what Amy Binder and colleagues refer to as the constitutive elements of culture, including "the diverse meanings and beliefs that individuals and groups adopt to interpret their life experiences and, equally important, how such life experiences are in turn consequential in their social lives." ${ }^{15}$ Migrants' who continue to participate in different materialist and recreational activities, ways and manner of communication, and social institutions including the Catholic Church and neighborhood associations while abroad reproduce and, therefore, reaffirm their membership in the social life of the hometown. Engaging in cultural repertoires of community also deemphasizes perceived or actual status differences that often accompany migrants' upward social mobility brought about by living and working abroad. Since the migration experience changes the material status of migrants, individuals who participate in club activities in the hometown have to strike a delicate balance in how they 
display their wealth and social status difference and maintain social solidarity and mutually recognized ideas of community with residents.

For example, when migrants go abroad they often learn a new language (e.g., English), adopt a new style of dress typical of the destination country, adopt new cultural practices perceived as "modern" (e.g., tattoos, piercings), and engage in conspicuous forms of consumption that together signal ascendance to a new social location, which may create social distance and sometimes jealousy. The social status differences affirmed by the migration experience are partially counteracted by practicing cultural repertoires and sharing their wealth and success with hometowners. When migrants maintain residences, visit frequently or for extended periods, continue to operate businesses from abroad, send remittances, bring home gifts for family, close friends, and acquaintances during visits, speak their native tongue, meet ethnic obligations (e.g., tequios or faenas) and wear traditional dress, they communicate solidarity, even if the activities are enabled by social mobility abroad. Migrants also partake in and host parties, rodeos, and church celebrations, financially support cultural traditions and community festivals (e.g., the annual patron saint festival) from abroad, and buy drinks and dinners for friends and acquaintances. These activities help preserve solidaristic ties with residents and influence recognition of social membership in the hometown community when membership is no longer tied to territorial residence. Engaging in cultural repertoires helps preserve imagined meanings of community that trespass national political borders in places that experience and are influenced by international migration. ${ }^{16}$

The reproduction of cultural repertoires enables migrants who achieve new levels of social mobility abroad to preserve their social position as a member of the community even while residing abroad. I expect that those migrants who practice cultural repertoires are also those who are more likely to have or are willing and interested in constructing bridging ties. ${ }^{17}$ Those migrants who have wider social network ties or are able to construct ties anew, and who participate in cultural practices, norms, and values that communicate solidarity, are those most likely to have the highest degree of community inclusion in transnational partnerships despite achieving new levels of wealth and experience relative to those remaining behind.

\section{COMMUNITY INCLUSION IN TRANSNATIONAL PARTNERSHIPS}

Community inclusion refers to the extent to which locals are involved in the transnational coproduction of public goods-selecting, volunteering, monitoring, negotiating, planning, and donating labor and resources to projects. Community inclusion is important to transnational partnerships for two reasons. First, the social base provides migrant club leaders absent from the hometown with local resources that help achieve project goals. Migrants' social ties support the coproduction 
endeavor in migrants' absence in several important ways. Local citizens monitor coproduction projects, ensure timely completion and quality standards, volunteer labor and contribute personal and community resources, put pressure on local officials to meet matching contributions, and regularly interface with local officials regarding project selection, materials and machinery, implementation, and technical planning. Without local support from the social base, migrant clubs must attempt to manage coproduction partnerships entirely from abroad or have the means to visit (e.g., legal status, time, energy, resources to cross the border) to meet with officials and plan and execute public goods projects. Without the "eyes and ears" of local citizens, transnational projects are vulnerable to corruption by local government and other nonstate actors. ${ }^{18}$ Reliable local community partners provide an important check on public agents and improve the likelihood that transnational collective action achieves the desired project goals.

Second, community inclusion, especially the inclusion of bridging social ties, increases the legitimacy and representativeness of the coproduction process since it includes more social actors and interests of different social segments of the community. Limited bridging ties can be problematic for a couple of reasons. Limited bridging ties may mean migrant club members are more likely to be perceived as social outsiders who lack information about norms of reciprocity and obligation, and the needs of the local citizenry. These "social gaps" of trust beyond migrants" social base of support undermine collective action efforts because citizens may rally to challenge the HTA as the representative voice of the community and work at cross-purposes. ${ }^{19}$ When social ties are lacking, the selection of coproduction projects with the local government reflects migrant desires and those of their close social ties to the exclusion of other societal interests. This exclusion may renew or create social divisions between migrant and nonmigrant households in the hometown and ignite questions about who belongs and who is really a member of the community with the authority to make decisions in public affairs when territorial residence is not the only factor that determines membership.

From the perspective of territorial citizens, exclusion from the coproduction process may undermine their social and political location. Exclusion from coproduction sends the message that political participation is hierarchical, and that one's access to and influence in political deliberations is materially conditioned. And because coproduction involves the state, when elected representatives privilege the voice of migrants over their constituents, they diminish the inherent value of (territorial) participation in politics. In places with substantial emigration, an active, organized group of migrants with resources to wield power and influence can diminish political membership and participation of territorial residents when residents are excluded from the coproduction process. When the voices of emigrants are louder than the voices of territorial citizens, or when they represent a narrow group of interests based on migrants' close social ties, migrant groups' transnational collective action becomes an instrument of what Weber called 
social closure-the process by which social collectives seek to maximize rewards by restricting access to resources and opportunities or in which resources and opportunities are restricted to a limited circle of social actors who are eligible. ${ }^{20}$ Transnational coproduction creates social closure when migrants act as if they are still territorial residents of the hometown without renegotiating their social membership in the community through the maintenance and construction of a wide array of social ties and practice of cultural repertoires and speak on behalf of the community of territorial residents without the legitimate authority to do so.

When emigrants exercise political voice after exit and that political voice is not predicated on mutual recognition of community membership, coproduction distances residents from making the decisions that affect their quality of life. Migrant transnational collective action that is exclusionary may displace residents from participation in the democratic political process, which is supposed to serve as a vehicle for interest representation and mechanism of social and political accountability in local governance. To overcome the inherent paradox in exercising voice and exit simultaneously, migrants must renegotiate their membership in the hometown community, which is facilitated by their degree of social embeddedness in the hometown community and includes local residents in coproduction; the broader the social network, the more successful the partnership.

\section{LOCAL GOVERNMENT ENGAGEMENT IN TRANSNATIONAL PARTNERSHIPS}

The structure of the social base in origin communities explains the degree to which transnational partnerships are inclusive of a broad, representative group of local citizens. However, since coproduction is a public-private partnership between organized migrant groups and local government, I also consider the factors that incentivize (and disincentivize) local government authorities' engagement in the process. Since coproduction requires complementary public financing from local government it is also necessary to assess what factors affect the quality of government engagement.

The degree to which local government provides complementary inputs to coproduction in the form of monetary and in-kind resources, project selection and planning, technical support, labor, and quality control is likely to vary across hometown settings. I argue two distinct but related factors affect local government engagement. First, government capacity determines political officials' ability to provide complementary inputs and their capacity depends, in part, on the organizational competence of local officials such as the public resources in the budget, their level of expertise, training, and professionalism. Second, when political officials are facing the possibility of their political party gaining or losing office and voters are actively engaged in making requests (or demands) for public goods, local political officials are likely to be more engaged in coproduction projects. In 
democratic systems with multiparty elections, government officials' incentives to cooperate with HTAs are likely shaped by local electoral incentives. ${ }^{21}$ In the Mexican system, local officeholders cannot run for reelection for municipal president. As a result, competition between political parties is an important factor in determining when local government takes an active approach toward the transnational partnership. Taken together, both demand-side and supply-side factors explain the degree to which local government officials engage in the coproduction project process.

On the supply side, government contributions to partnerships are most often shaped by local budget constraints and the size of the origin community, but also the training and professionalism of local government officials and staff. ${ }^{22}$ Government engagement suffers if local officials do not have the training and skills to provide technical plans and organize project budgets, or the ability to maintain authority and provide security over their political territory. In short, government engagement in coproduction is more likely in political contexts in which local government has what Michael Mann calls “infrastructural power." Infrastructural power refers to the capacity of the state to actually penetrate civil society and implement logistical political decisions through those realms. ${ }^{23}$ Furthermore, as Wendy Pearlman argues, state capacity is an important factor to be evaluated rather than a property to be assumed when analyzing sending-state experiences with mass migration. ${ }^{24}$ Explaining variation in local government engagement necessitates a description of the real and effective authority of the government, which is captured by the size of the origin community, fiscal budgetary constraints, and the degree of professionalization of political officials and their staff.

On the demand side, attention to the ways in which electoral systems channel societal interests for social spending and public goods delivery determines when local government officials are more likely to be engaged. Since electoral competition has become fiercer with subnational democratization, incumbent political parties interested in electoral victory may use public spending and remittance matching for public goods as a strategy to curry political favor in local political districts. Incumbent political officials may respond to increasingly competitive elections by using spending strategies that either win over swing voters or reward loyal party supporters.

Whether incumbents use broad, programmatic, or targeted spending to garner political support happens according to two separate logics according to the distributive politics literature. According to the first logic, incumbents use programmatic spending on public works to win over swing voters in highly competitive districts. ${ }^{25}$ Programmatic spending increases public goods provision, which benefits everyone including both loyal constituents and swing voters. We should expect, then, that in highly competitive municipalities, incumbent political officials will by more engaged in transnational partnerships that provide public goods to win over a larger share of the electorate in order to win elections. According 
to a second logic, in political party strongholds incumbent parties may choose to reward core supporters with targeted spending because they only need to win by a small margin called the selectorate. ${ }^{26}$ Targeting goods directly to core constituents allows incumbents to reward those who consistently turn out to the polls to support them. If political officials follow this strategy, we should expect less government engagement in party strongholds where incumbent officials need not rely on programmatic spending on public goods as a winning strategy. To understand the variability in municipal engagement in coproduction projects, I also assess how municipal officials respond to changing municipal electoral pressures and the competitiveness of multiparty elections. ${ }^{27}$

In short, understanding the variation in local government engagement requires a careful evaluation of the political conditions that incentivize officials' degree of participation and the real and effective authority that they have while holding office. Local government must use public resources and know-how to meet their obligations in coproduction projects, but how much they complement the coproduction process with time, energy, and resources is a function of their capacity and the perceived political payoff of doing so. But why can't HTAs simply provide public goods and services on their own? Why do they need government partners and the support of public agencies in the sending state?

There are a few reasons why HTAs need some engagement from the local or subnational government in decentralized political systems. First, migrant HTAs are made up of immigrants in the destination country who volunteer their free time, energy, and resources to improve social welfare in their hometown communities. While some associations have become formal organizations with 501c(3) status and maintain high levels of capacity (e.g., stable and growing membership and resource base, skills in organizing and fundraising, membership in state-level federations of clubs with information and resources to draw from), very few HTAs are likely to have the requisite training, support, energy, resources, and economies of scale to independently coordinate public goods without input and support from government authorities. Most HTAs are social groups that range in size but have a core group of leaders with a less involved membership base. This means that club leaders are most often the ones who do the bulk of the activities required to produce public projects back in the hometown. Migrant leaders organize, fundraise, and oversee development projects often in their spare time, on weekends, over telephone and email, and in meeting places at one another's houses. These club leaders are rarely professionally trained engineers and public administrators and typically do not have a full-time staff to support transnational efforts. HTAs need the financial and technical support of local government in order to meet the demands of implementing public works projects from beyond national borders.

Second, local government in many decentralized federal systems bears the administrative and political responsibility to provide public goods and services to the citizenry. Local government is the entity charged with caring and administering 
public lands. For many public goods projects, HTAs, at a minimum, need the approval and legal permission from local government to access public territory to build cemeteries, bridges, roads, sidewalks, water pipes, light poles, and the like, in the hometown.

Third, as competition for local public office becomes more competitive, local incumbents must build a base of support to secure electoral victory. If migrant HTAs are providing public goods without the cooperation of local government, elected officials may perceive migrant groups as a challenge to their legitimate authority and work to demobilize HTA development efforts or seek to offload responsibility completely onto migrant groups. In this vein, the size of the origin community where coproduction projects are proposed and carried out is a likely factor in the degree of local government engagement. In larger, wealthier communities in which political officials face fewer fiscal constraints to spend on public goods, local government actors may be less inclined to commit resources to the coproduction effort because officials do not need migrants to fulfill their administrative and political obligations. It may be more likely the case that smaller communities and those with more restricted social spending budgets are more inclined to support transnational coproduction projects with migrant groups abroad in order to subsidize local social spending initiatives with complementary resources from abroad.

Finally, if migrants' social bases are diffuse networks of engaged citizens and their civic associations, lack of government engagement signals to a segment of the voting public that local administration is wanting, which may harm incumbents come election time or create more discord and distrust in politicians. The local political context, including the preexisting character of political competition and institutional capacity, helps explain the extent to which local government engages in coproduction projects with migrant transnational partners.

\section{HOW COMMUNITY INCLUSION AND GOVERNMENT ENGAGEMENT ORGANIZE PARTNERSHIP TYPES}

How do partnerships organizationally vary? I conceive of the coproduction process as a relational space in which migrant and political actors interact in different social and political settings. ${ }^{28}$ Figure 2 represents a conceptual space in which community inclusion (horizontal axis) and government engagement (vertical axis) intersect at different points and times along the two dimensions. The two dimensions of coproduction are dynamic, as are the interactions between different sets of agents (migrant groups, political officials, local citizens, and citizen groups). I emphasize that it is this dynamism, this variation, that determines political outcomes.

Different combinations of community inclusion and government engagement yield coproduction "types" identified in the four quadrants of the diagram. When 


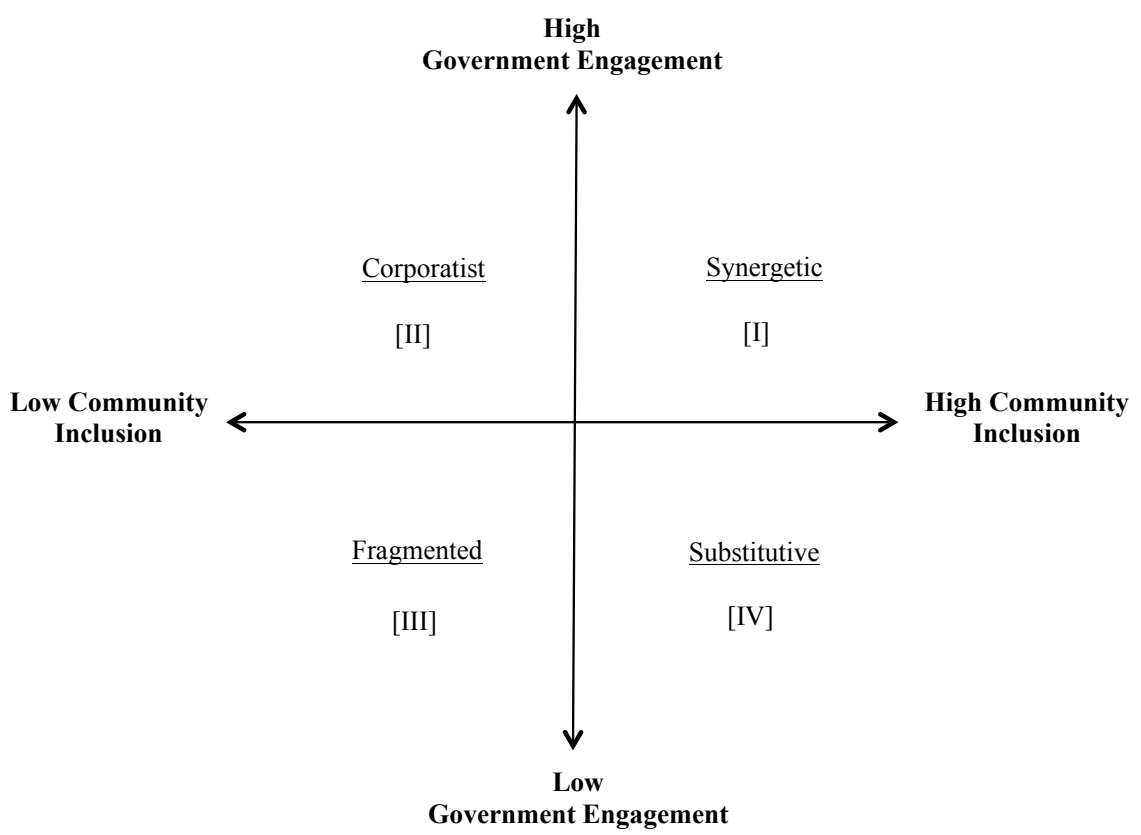

FIGURE 2. Conceptual diagram illustrating how community inclusion and government engagement interact to produce four organizational types of transnational coproduction.

inclusion and engagement are high (quadrant I), I call this a synergetic partnership. Synergetic coproduction is characterized by cooperative engagement among migrant HTAs, local government, and local citizens. All groups collaborate to coordinate projects, including deliberation over project selection, implementation, and oversight. I argue that as coproduction partnerships become more cooperative and inclusive, the likelihood that positive spillovers from coproduction affect civic and political participation in the hometown beyond project governance increases. In turn, as more local citizens participate in civic and political institutions-for example, voting and community associations-more citizens' interests will be represented in the political sphere of decision-making and government responsiveness will improve.

Synergetic coproduction is more likely to lead to greater civic and political engagement because citizens and government actors become embedded in more routinized forms of interaction and participation. Since citizens are more involved in making and shaping social welfare decisions that directly affect their lives, they are more likely to engage in politics as they learn what the democratic process can do to improve their lives and solve local problems that affect the citizenry. In other words, more participation in coproduction is likely to increase the political efficacy and mobilization needed for political participation in other spheres, including local 
elections. More civic and political engagement of the citizenry, in turn, will yield a more responsive government apparatus since citizens are willing to put pressure on government actors through social mechanisms. Information that citizens have about public budgets and the kind of decisions government actors make occur in closer proximity to their constituents. When citizens, migrants, and elected representatives are more enmeshed in decision-making over public goods and services, more local democratic engagement and responsive governance ensues.

By contrast, when both indicators are low (quadrant III), a fragmented partnership emerges. This form is inherently vulnerable to co-optation by the state and, in some instances, the HTA. The exclusion (intentional or unintentional) of local residents and low government engagement coupled with migrants' interrupted presence or physical absence from the hometown during project activities often leads to project mismanagement, appropriation of funds, and ultimate failure. Fragmented coproduction is most often associated with a worsening of statesociety relations and a decline in citizen trust and engagement in local political life. ${ }^{29}$ Fragmented partnerships signal less information sharing between migrants and residents about local government. When citizens are less involved in the coproduction process there are fewer social actors to monitor local government and provide oversight in project planning, implementation, and quality control. The lack of monitoring by residents and migrants who live abroad makes corruption and rent-seeking behaviors more likely, which often leads to the failure of the transnational partnership.

I discuss two additional intermediary cases in which either inclusion or engagement is low (or high) along the continuum of the axes. These intermediary forms I refer to as corporatist partnerships (quadrant II) and substitutive partnerships (quadrant IV). Corporatist coproduction is an organizational form in which high government engagement but low citizen inclusion links migrants' organized interests directly with the decisional structure of the local government. Cooperative relations between HTAs and local government grant HTAs privileged access to political officials to set the local public policy agenda. When migrants' public goods preferences predominate, the unequal distribution of resources toward migrant- and state-preferred public projects crowds out the voices of residents with a stake in public goods decisions that directly affect their lives. I hypothesize that corporatist coproduction affects local democratic engagement in two ways: political disengagement or short-run political activism.

Corporatist coproduction, characterized by low levels of community inclusion but high government engagement, suggests a narrow representation of interests reflected in project selection and implementation. If the migrant club lacks the ability or desire to retain some autonomy from the state, then migrant and state interests become the same and migrant groups may be vulnerable to clientelistic capture. On the one hand, citizen exclusion may trigger short-run political activism. When citizens perceive migrant groups' participation being privileged by the 
local government or perceive migrants as agents of the state, this crowding out may induce greater political awareness, interest, and mobilization to participate in formal politics. Citizen exclusion may introduce more short-term political participation at the local level as opposition political parties seize the opportunity to garner disaffected citizen voters. Citizens may be more encouraged to use the ballot box to punish incumbents for poor performance while in office (and reward incumbents who perform well) because they witnessed government mismanagement firsthand. On the other hand, citizen exclusion from the coproduction process may lead locals to distrust political (and migrant actors) and politics more generally. This decline in political interest may create disenchantment with local politics and a decline in political engagement.

Finally, substitutive coproduction refers to low government engagement and high community inclusion. In substitutive coproduction, local government provides some, albeit minimal, complementary inputs to public projects. Since cofinancing from other levels of government (state and federal) often accompanies coproduction, higher tiers of government and migrant HTAs subsidize local government provision. HTAs, in coordination with local citizens and citizen groups, organize project selection, planning, and implementation, leaving local government largely off the hook for service provision. In substitutive coproduction, government responsiveness is likely to wane as HTAs, citizens, and state and federal cofinancing partners subsidize local public works provision through coproduction..$^{30}$ In extreme cases, migrant groups may begin to challenge local officials for political power and authority and become the apex provider of local public goods and services. Substitutive coproduction is most likely to affect government responsiveness in public goods provision. If migrant groups subsidize social welfare spending and complete the lion's share of effort in coordinating public works, local governments are likely to allocate less resources for public social welfare, thus allowing them to shift spending patterns to alternative budget categories.

It is important to stress that coproduction cases are likely to be situated at other points along the conceptual continuum. The four cases I analyze reflect extreme combinations of inclusion and engagement and provide a set of testable hypotheses for the empirical chapters that follow. Additional cases of coproduction include transnational partnerships that come together for the purpose of one and only one project. I do not discuss such cases of one-off coproduction, but they frequently emerge. Other cases of coproduction are also likely affected by local factors that are not directly related to political institutions and social embeddedness including, for example, economic crisis and drug-related violence, which affected the United States and Mexico in the period of study. These hybrid cases are likely closer to reality than the stark characterizations I present here. I explore the role of economic crisis and public insecurity and violence more in the qualitative empirical chapters ahead..$^{31}$ 


\section{HOW U.S. AND MEXICAN CHARACTERISTICS SHAPE}

\section{TRANSNATIONAL PARTNERSHIPS}

Certainly, other factors are important to coproduction processes, including migrants' length of stay in the destination country, ecological features of the destination locale such as membership size, network dynamics, proximity of HTAs to other clubs and home country consulate, membership in state-level federations (especially in the Mexican case), as well as the internal structure of club decision-making. All of these factors vary across transnational partnerships. The point is not that other factors are irrelevant. Rather, I argue they are most likely to affect the configurations of partnerships through their effect on community inclusion and government engagement. In other words, the role of HTA capacity and U.S. and Mexican place-based characteristics, for example, may be endogenous to the community inclusion and government engagement that structure transnational partnerships.

One could imagine that the capacity of HTAs to carry out coproduction activities, most notably their fundraising ability and club internal organizational structure, is conditioned, in part, on the very factors that I argue affect migrant social embeddedness and thus community inclusion, including the size of the U.S. destination membership base. HTAs with more club members have access to more social ties from which to draw support. Since they are embedded in larger social bases they may expand community inclusion beyond their immediate bonding network. And because they have larger social networks to draw on for fundraising and coproduction support, they may also have a larger resource base to invest in public works from abroad.

Additionally, clubs that are members of state-level federations may develop more direct vertical links to political officials in the home country, enabling more opportunities to interface with elected representatives in the origin and destination country. More opportunities to interact with political authorities through state-level federations may, in turn, encourage more government engagement by way of leveraging bargaining power over municipal authorities with the collective power and voice of many migrant clubs from the same state of origin. In the theoretical framework I offer here, I hold HTA club capacity constant in an effort to maintain parsimony. I analyze greater variation in HTA capacity and the size of the membership network of the HTA abroad, among other factors, in the upcoming empirical chapters and report their effects on the organization of partnerships in chapters 4 and 6 .

\section{SUMMARY}

In this chapter, I lay the foundations for the subsequent empirical analysis of migrant collective engagement in local public goods provision. I propose that 
transnational partnerships produce systematic effects on local political engagement and responsive governance. The typological theorizing I present describes the reasons why partnerships vary and how more synergetic, corporatist, substitutive, and fragmented partnerships change local democratic governance including state-society relations and political engagement. The argument advanced here is not meant to be a model that replaces the role of other factors that affect civic and political engagement and government responsiveness. Rather, I seek to bring greater attention to the role of transnational migrant actors and the variation in organizational forms of a transnational institution (coproduction partnerships) to better understand how civic and political engagement waxes and wanes in local democracies experiencing international migration. This theory is not meant to replace theories of electoral institutions, economic development, and social capital whole cloth but is instead intended to complement existing theories and explain more variation in political participation and the sources of change in government performance.

In the next chapter, I describe the macrostructural factors that gave rise to the Mexican sending state's outreach policies with the migrant diaspora in the United States, which culminated in the 3x1 matching grants program. The 3x1 Program administers coproduction projects between migrant clubs and the local, state, and federal governments in Mexico. 